\title{
CATALYTIC OXIDATION OF ETHYLENE GLYCOL BY DIOXYGEN IN ALKALINE MEDIUM. THE NEW EXAMPLE OF ONE-STAGE OXIDATIVE CLEAVAGE OF C-C BOND
}

\author{
N. M. Emanuel Institute of Biochemical Physics, Russian Academy of Sciences \\ 4, Kosygin str., 119334 M oscow, Russia; Chembio@sky.chph.ras.ru
}

Received: November 16, 2010 / Revised: December 14, 2010 / Accepted: April 03, 2011

(c) Sakharov A., Sakharov P., Zaikov G., 2012

\begin{abstract}
Reaction of low temperature oxidations of ethylene glycol (EG) by molecular oxygen in the presence of salts of bivalent copper and alkali both in water and in waterless solutions was investigated. It was found that at low (close to room) temperatures and in waterless solutions the basic product of EG oxidation is formic acid. Rise in the temperature from $290-315 \mathrm{~K}$ to $350-360 \mathrm{~K}$ or reaction flow in water-containing solutions leads to sharp change of reaction direction. EG in these conditions is oxidized with primary formation of glycolic acids salts. The change in the reaction direction is connected, apparently, with decrease in the stability of chelate complexes of $\mathrm{Cu}^{2+}$ ions with dianionic form of EG. The mechanism of glycolic acids formation includes, possibly, a stage of two-electronic reduction of $\mathrm{O}_{2}$ in the reaction of dioxygen with monoanionic forms of EG, coordinated on $\mathrm{Cu}^{2+}$ centers.
\end{abstract}

Keywords: oxidation, oxygen, ethylene glycol, $\mathrm{Cu}^{2+}$ ions, formic and glycolic acids.

\section{Introduction}

The chemical industry is high on the list among those environmentally hazardous. In this connection the search of new chemical processes with low-level consumption of energy and minimum formation of byproducts is in high demand. In the first place it concerns processes of organic substances oxidation by oxygen, which allow to produce a wide spectrum of products for various industries. The leader among the authors whose works are devoted to the creation of new highly selective processes of liquid-face oxidation by oxygen was academician N.M. Emanuel. He was convinced that the most promising direction of liquid-phase oxidation reactions selectivity increasing is the use of metal complexes as the catalysts. In the present work kinetic regularities of EG autooxidation in the presence of $\mathrm{Cu}^{2+}$ ions and the bases are investigated. As it will be shown below, changing of the process conditions allows to pass from highly effective EG to formic acid oxidation to a reaction with primary formation of glycolic acid. It was found that at optimal conditions the rates of lowtemperature EG oxidations are close to the rates of enzymatic reactions catalyzed by dioxygenases.

\section{Experimental}

Oxidation of EG by oxygen in various solvents at 300-360 K was carried out in a glass reactor equipped with a mechanical stirrer with continues supply of oxygen. At oxygen elevated pressures (to $1 \mathrm{MPa}$ ) the reaction was carried out in a steel reactor (the volume of 0.11 ). In both cases stirring was done by mechanical mixers ( $1000 \mathrm{rpm})$.

Reaction mixtures were prepared by consecutive introduction of salts of bivalent copper $\left(\mathrm{CuCl}_{2} \cdot 2 \mathrm{H}_{2} \mathrm{O}\right.$, $\mathrm{CuSO}_{4} \cdot 5 \mathrm{H}_{2} \mathrm{O}$ or $\left.\mathrm{Cu}(\mathrm{Ac})_{2} \cdot 2 \mathrm{H}_{2} \mathrm{O}\right)$ and alkalines $(\mathrm{NaOH}$ or $\mathrm{KOH}$ ) in water or waterless solutions of EG. Alkali addition to solutions of salts of copper, containing EG, leads to formation of bright dark blue complexes $\mathrm{Cu}^{2+}$, stable at $\mathrm{pH} 8-14$. After addition of alkali oxygen was carefully blown off and the reactor was pressurized. Oxygen absorption started after the beginning of the reaction mix stirring.

Reaction rate was measured by the rates of oxygen absorption, alkali and EG expenditure and accumulation of EG oxidation products. Acids formed in the course of reaction were analyzed by HPLC method on "Millipore Waters" with the use of UV detector. Concentration of EG was determined by GLC [1]. 


\section{Results and Discussion}

In neutral solutions EG does not react with dioxygen with measurable rates at low $373 \mathrm{~K}$. Alkaline solutions of EG in the absence of copper salts are not oxidized by oxygen at low temperatures either. Thus, similar to oxidation of primary and secondary alcohols and polyols [2-5], oxidation of EG at low temperatures by oxygen is possible only in the presence of the twocomponential catalytic system $\left\{\mathrm{Cu}^{2+}+\right.$ base $\}$.

Practically immediately after alkali introductions into a solution containing EG and salt of copper, intensive absorption of oxygen starts. Similarly to oxidation of other hydroxy-containing compounds in the presence of copper ions and basis [6], activation of EG in relation to oxygen obviously occurs only after substrate transfer in active anionic form.

The curves of oxygen absorption at the oxidation of $20 \%$ solutions of EG in tert-butyl alcohol at $323 \mathrm{~K}$ in the presence of $5 \cdot 10^{-3} \mathrm{M} \mathrm{CuCl}_{2} \cdot 2 \mathrm{H}_{2} \mathrm{O}$ and various quantities $[\mathrm{KOH}]$ are presented in the Fig. 1 .

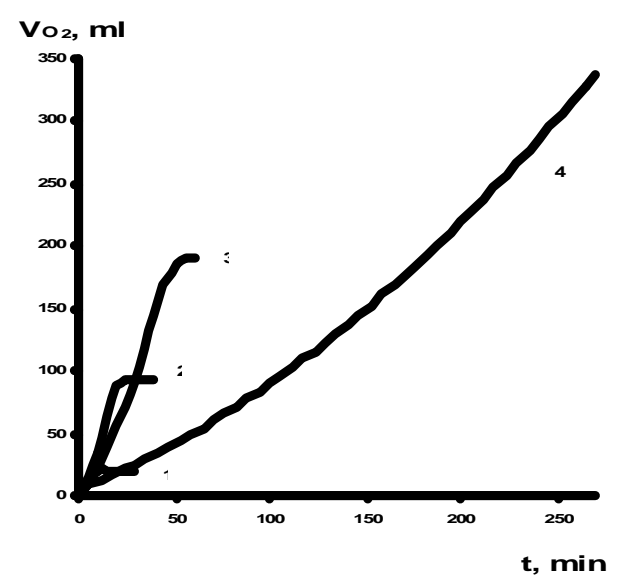

Fig. 1. The curves of oxygen absorption in the reaction of EG oxidation in the presence of various quantities of the granulated alkali: $C_{K O H}(\mathrm{~g} / \mathrm{l}) 4$ (1), 14 (2), 25 (3) and 50 (4); $V=25 \mathrm{ml}$; $\left[\mathrm{CuCl}_{2} \cdot 2 \mathrm{H}_{2} \mathrm{O}\right]=5 \cdot 10^{-3} \mathrm{M} ; P_{O 2}=0.1 \mathrm{MPa} ;[\mathrm{EG}]_{0}=200 \mathrm{~g} / \mathrm{l} ;$ solvent is tert-butyl alcohol; $T=323 \mathrm{~K}$

As can be seen from Fig. 1, in the range of $\mathrm{KOH}$ concentration 4-25 g/l $(0.07-0.45 \mathrm{M})$ initial rate of absorption of oxygen practically does not depend on alkali concentration (Fig. 1, curves 1-3). At higher $\mathrm{KOH}$ concentration the rate of oxygen absorption considerably decreases (Fig. 1, curve 4), which is connected, apparently, with deactivation of the catalyst owing to formation of inactive hydroxy-complexes of bivalent copper in the presence of alkali surplus. Similar kinetic laws of EG oxidation are received at use of $\mathrm{NaOH}$ as basis. The maximum rates of oxidation in this case are close to the rates of the reaction in the presence of $\mathrm{KOH}$. However, a small period of autoacceleration due to slower dissolution of $\mathrm{NaOH}$ granules in comparison with $\mathrm{KOH}$ in the solutions was observed.

During EG oxidation in the presence of copper salts and alkali the main products are acids. After alkali neutralization by acids oxygen absorption completely stops (Fig.1, curves 1-3). Introduction of a new portion of alkali completely restores the initial rate of oxygen absorption. The variation in the amount of the entered alkali allows regulating the depth of EG oxidation. The use of the method of introduction of fractional additives of alkali in the reaction course allows to reach very high depths of EG transformation (over $95 \%$ ) at the highest rates of the process.

The rates of oxygen absorption at EG oxidation both in water and waterless solutions linearly grow with the growth of $\mathrm{Cu}^{2+}$ salts concentration in the range of 0 to $2 \cdot 10^{-2} \mathrm{M}$. Further increase in copper ions concentration does not change the reaction rate. It is connected, apparently, with the fact that in these conditions (high concentration of $\mathrm{Cu}^{2+}$ ) a limiting stage of reaction is the rate of EG deprotonation.

In Fig. 2 the dependence of oxygen consumption rate on initial EG concentration is presented. The rise of EG concentration in a solution of tert-butyl alcohol from 0 to $50 \%$ leads to linear increase in the rate of oxygen absorption. The further increase of EG concentration leads to considerable decrease in the rate of the process. It is connected, apparently, with decreasing of donor properties of anion form of EG. Earlier it was shown [7] that aliphatic alcohols are oxidized with the highest rates only in aprotic solvents. Similar influence of the nature of a solvent used on the rate of EG oxidation is observed too.

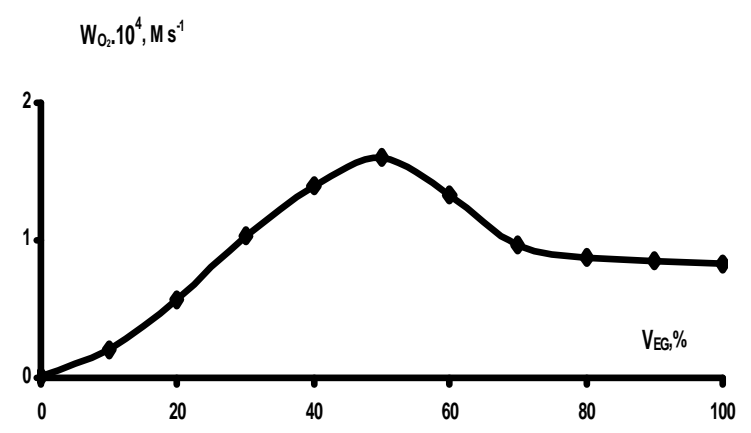

Fig. 2. Dependence of EG oxidation rate on its concentration (vol \%) in a solution of tert-butanol: $\left[\mathrm{CuCl}_{2} \cdot 2 \mathrm{H}_{2} \mathrm{O}\right]=5 \cdot 10^{-3} \mathrm{M} ;[\mathrm{KOH}]_{0}=0.5 \mathrm{M}, P_{O 2}=0.1 \mathrm{MPa}$; solvent is tert-butanol; $T=323 \mathrm{~K}$ 
As can be seen from Table 1 the highest rates of oxygen combustion in the reaction of EG oxidation are reached when the most polar aprotic solvents, such as DMSO and DMF are used. At the use of H-containing solvents the reaction rate is decreasing and in water containing solvent makes not more than 2-3\% from the EG in DMSO oxidation rate value.

Table 1

\section{Rates of oxygen absorption $\left(W_{O 2}\right)$ and selectivity of formic acid formation $\left(S_{\mathrm{HCOOH}}\right)$ at EG oxidation in various solvents}

\begin{tabular}{|l|c|c|}
\hline \multicolumn{1}{|c|}{ Solvent } & $W_{\mathrm{O} 2} \cdot 10^{4} \mathrm{M} / \mathrm{s}$ & $S_{\mathrm{HCOOH}}, \%$ \\
\hline DMSO & 4.0 & 84 \\
\hline DMF & 2.8 & 70 \\
\hline EG,100\% & 1.0 & 94 \\
\hline tert-Butanol & 0.8 & 90 \\
\hline $\mathrm{H}_{2} \mathrm{O}$ & 0.1 & 30 \\
\hline
\end{tabular}

Notes: $[\mathrm{EG}]_{\mathrm{o}}=20 \mathrm{vol} \%,\left[\mathrm{CuCl}_{2} \cdot 2 \mathrm{H}_{2} \mathrm{O}\right]_{\mathrm{o}}=5.10^{-3} \mathrm{M}$, $[\mathrm{KOH}]_{0}=0.5 \mathrm{M}, T=323 \mathrm{~K}, P_{O 2}=0.1 \mathrm{MPa}$.

The analysis of the products of EG oxidation by GLC and HPLC methods has shown that in the course of reactions in all investigated conditions acids are formed as the basic products of reaction. Depending on the process conditions EG can be oxidized to formic acid (with selectivity close to $100 \%$ ) or with primary formation of glycolic acids.

At optimum conditions (waterless solutions and low temperatures) salts of formic acid are the unique products of EG oxidation (reaction 1):

$$
\mathrm{HOCH}_{2}-\mathrm{CH}_{2} \mathrm{OH}+1.5 \mathrm{O}_{2}+2 \mathrm{KOH} \rightarrow 2 \mathrm{HCOOK}+3 \mathrm{H}_{2} \mathrm{O}
$$

In Table 1 along with the rates of oxygen absorption data, the data on selectivity of formation of formic acid on EG concentration is presented. The greatest selectivity of formation of formic acid, coming nearer to $100 \%$, is observed in case of oxidation of pure EG and $25 \%$ of solutions in tert-butyl alcohol. Oxidation of water solutions of EG leads to sharp decrease in the reaction rate. In the presence of water, unlike at EG oxidation in waterless environments, the basic product of EG oxidation is not formic but glycolic acid (reaction 2). Potassium salt of glycolic acid at low temperatures in the presence of alkali and $\mathrm{Cu}^{2+}$ salts is stable.

$$
\mathrm{HOCH}_{2}-\mathrm{CH}_{2} \mathrm{OH}+\mathrm{O}_{2}+\mathrm{KOH} \rightarrow \mathrm{HOCH}_{2}-\mathrm{COOK}+2 \mathrm{H}_{2} \mathrm{O}
$$

In Table 2 the data on the rate of oxygen absorption and selectivity of formic and glycolic acids formation in $\mathrm{H}_{2} \mathrm{O}$ - tert-butanol solutions is presented. Increase in concentration of water above $10 \%$ in the mix of $\mathrm{H}_{2} \mathrm{O}-$ tert-butyl alcohol leads to sharp decrease in the rate of absorption of oxygen and to considerable increase of glycolic acids concentration in products of EG oxidation.
In Table 3 the rates of oxygen absorption data at various temperatures are presented. In the range of temperatures from 300 to $340 \mathrm{~K}$ classical Arrhenius dependence is observed: energy activation is $43 \mathrm{~kJ} / \mathrm{mol}$. However at the temperature rise above $343 \mathrm{~K}$ the rate of absorption of oxygen does not increase. It is possible to see that at the rise in temperature from 340 to $350 \mathrm{~K}$ in the reaction of oxidation of $20 \mathrm{vol} \%$ solution of EG in tertbutyl alcohol selectivity of formic acid formation decrease from 80 to $55 \%$. It is connected, apparently, with the rise of a rate of oxidation of $\mathrm{K}$-salts of $\mathrm{EG}$ to $\mathrm{CO}_{2}$.

Oxidation of EG in a bulk at two temperatures 323 and $363 \mathrm{~K}$ was studied too (Table 4).

Table 2

Rates of $\mathrm{O}_{2}$ absorption $\left(\mathrm{W}_{\mathrm{O}_{2}}\right)$ and selectivity of formic $\left(S_{\mathrm{HCOOH}}, \%\right)$ and glycolic $\left(S_{\mathrm{HOCH}} \mathrm{COOH}, \%\right)$ acids formation in $\mathrm{H}_{2} \mathrm{O}$ - tert-butanol solution at various concentrations of $\mathrm{H}_{2} \mathrm{O}$ in a mix (vol \%)

\begin{tabular}{|c|c|c|c|c|c|c|}
\hline $\begin{array}{c}\text { Contents of } \\
\mathrm{H}_{2} \mathrm{O} \text { in the } \\
\mathrm{H}_{2} \mathrm{O}-\text { tert- } \\
\text { butanol mix, } \\
\text { vol \% }\end{array}$ & 0 & 5 & 10 & 25 & 50 & 100 \\
\hline$W_{\mathrm{O}_{2}} \cdot 10^{5}, \mathrm{M} / \mathrm{s}$ & 6.8 & 6.6 & 5.9 & 2.5 & 1.1 & 0.5 \\
\hline$S_{\mathrm{HCOOH}} \%$ & 96 & 93 & 91 & 77 & 45 & 40 \\
\hline$S_{\mathrm{HOCH}_{2} \mathrm{COOH}}, \%$ & 1 & 5 & 7 & 19 & 40 & 52 \\
\hline
\end{tabular}

Notes: $\left[\mathrm{CuCl}_{2} \cdot 2 \mathrm{H}_{2} \mathrm{O}\right]_{0}=5 \cdot 10^{-3} \mathrm{M} ;[\mathrm{EG}]_{\mathrm{o}}=20 \mathrm{vol} \%$, $[\mathrm{KOH}]_{0}=0.5 \mathrm{M}, T=323 \mathrm{~K}, P_{O 2}=0.1 \mathrm{MPa}$

Table 3

Rates of $\mathrm{O}_{2}$ absorption and selectivity of formic and glycolic acids formation at various temperatures

\begin{tabular}{|l|c|c|c|c|c|c|}
\hline Temperature, $\mathrm{K}$ & 303 & 313 & 323 & 333 & 343 & 353 \\
\hline$W_{\mathrm{O}_{2}} \cdot 10^{4}, \mathrm{M} / \mathrm{s}$ & 0.1 & 0.33 & 0.68 & 1.05 & 1.7 & 1.71 \\
\hline$S_{\mathrm{HCOOH}}, \%$ & 98 & 97 & 96 & 91 & 80 & 55 \\
\hline$S_{\mathrm{HOCH}_{2} \mathrm{COOH}} \%$ & 0 & 0.5 & 1 & 4 & 5 & 12 \\
\hline
\end{tabular}

Notes: $\left[\mathrm{CuCl}_{2} \cdot 2 \mathrm{H}_{2} \mathrm{O}\right]_{0}=5 \cdot 10^{-3} \mathrm{M} ;[\mathrm{EG}]_{\mathrm{o}}=20$ vol \%; $[\mathrm{KOH}]=0.5 \mathrm{M} ; P_{\mathrm{O}_{2}}=0.1 \mathrm{MPa}$; solvent - tert-butanol

Table 4

Rates of $\mathrm{O}_{2}$ absorption and selectivity of formic and glycolic acids formation at 323 and $363 \mathrm{~K}$

\begin{tabular}{|c|c|c|c|}
\hline$T, \mathrm{~K}$ & $W_{\mathrm{O}_{2}} \cdot 10^{4}, \mathrm{M} / \mathrm{s}$ & $S_{\mathrm{HCOOH}}, \%$ & $S_{\mathrm{HOCH}_{2} \mathrm{COOH}}, \%$ \\
\hline 323 & 1.0 & 95.0 & 3.5 \\
\hline 363 & 0.9 & 35.0 & 55.0 \\
\hline
\end{tabular}

Notes: $\left[\mathrm{CuCl}_{2} \cdot 2 \mathrm{H}_{2} \mathrm{O}\right]=5 \cdot 10^{-3} \mathrm{M} ;[\mathrm{KOH}]_{0}=0.4 \mathrm{M}$; $P_{O 2}=0.1 \mathrm{MPa} ;[\mathrm{EG}]_{0}=100 \%$ 
As can be seen from this table, the rise in the temperature to $313 \mathrm{~K}$ leads to decrease of the oxygen absorption rate and to the change of the process direction. If at low temperatures almost unique product of oxidation is formic acid, at $363 \mathrm{~K} \mathrm{EG}$ is oxidized mainly to glycolic acids.

Dependence of EG oxidation rate on partial pressure of oxygen is unusual for reactions of liquid phase oxidations of organic compounds. In Table 5 the data on the influence of $\mathrm{O}_{2}$ pressure on the rate and selectivity of EG oxidation to formic acid in tert-butyl alcohol are presented.

\section{Table 5}

Rates of KOH consumption and selectivity of formic acid formation at various pressures of oxygen

\begin{tabular}{|c|c|c|}
\hline $\begin{array}{c}P_{\mathrm{O} 2}, \\
\mathrm{MPa}\end{array}$ & $\begin{array}{c}\text { Rate of } \mathrm{KOH} \\
\text { consumption, } \mathrm{M} / \mathrm{s}\end{array}$ & $S_{\mathrm{HCOOH}}, \%$ \\
\hline 0.02 & $2.1 \cdot 10^{-5}$ & 45 \\
\hline 0.1 & $6.3 \cdot 10^{-5}$ & 90 \\
\hline 1.0 & $3.2 \cdot 10^{-4}$ & $\approx 100$ \\
\hline
\end{tabular}

Notes: solvent - tert-butanol; $[\mathrm{EG}]_{0}=25 \mathrm{vol} \%$; $\left[\mathrm{CuCl}_{2} \cdot 2 \mathrm{H}_{2} \mathrm{O}\right]=5 \cdot 10^{-3} \mathrm{M} ;[\mathrm{KOH}]_{0}=0.5 \mathrm{M} ; T=323 \mathrm{~K}$

Selectivity of formic acid formation was determined as the relation of the concentrations of $\mathrm{HCOOH}$ formed to the concentration of hydroxide potassium spent. It is well known that the rate of liquid phase oxidations of organic substrates in the presence of initiators or traditional catalytic systems in neutral environments practically do not depend on partial pressure of oxygen at $P_{O 2}$ from above $0.02 \mathrm{MPa}$ [8]. As can be seen from Table 4 a considerable growth of EG oxidation rate is observed at least up to $1 \mathrm{MPa}$ of $P_{\mathrm{O} 2}$ values. At the low pressure of oxygen $(0.02 \mathrm{MPa})$ not only low rate of oxidation of EG is observed, but low selectivity of formic acid formation as well. At elevated pressures of $\mathrm{O}_{2}$ and at low temperatures the unique product of reaction is $\mathrm{HCOOH}$.

\subsection{Catalytic Activities and Selectivities}

The kinetic regularities of EG oxidation by $\mathrm{O}_{2}$ resulted in an experimental part demonstrate that in the presence of ions of bivalent copper and alkali the reaction proceeds via an uncommon mechanism. An extraordinary strong dependence of the rate and the direction of EG oxidation on the nature of solvent used was found. Dependence of the rate and selectivity of oxidation on temperature is uncommon as well. Moreover, dependence of reaction rate on partial pressure of oxygen is atypical for reactions of liquid phase oxidations of organic substrates by oxygen.

On the basis of the received experimental data it is possible to draw a conclusion that in most cases (waterless environments, moderate temperatures) oxidation proceeds through the stage of chelate complexes formation between $\mathrm{Cu}^{2+}$ ions and dianionic forms of EG. Dark blue complexes of bivalent copper with dianionic form of EG are formed practically immediately after alkali addition to solution consisting of EG and $\mathrm{Cu}^{2+}$ salts. Such complexes possess very high stability. They have been allocated from solutions and characterized by an X-ray analysis [9].

It is known that bivalent copper ions can catalyze oxidation by molecular oxygen of some easily oxidized compounds such as phenols, pyrocatechol, etc., which are in anionic form. In such reactions, as it has been shown [10], bivalent copper ions act as oxidants and the role of oxygen consists in reoxidation of unstable $\mathrm{Cu}^{+}$cations, formed at the first stage of the reaction, to $\mathrm{Cu}^{2+}$ ions. On the contrary, $\mathrm{Cu}^{2+}$ complexes with dianionic form of EG in the absence of oxygen are stable, which can be confirmed by spectral analysis of such complexes. Thus, the mechanism of the reaction which implies the stage of EG ions oxidation by bivalent copper ions (reaction 3 ) must be excluded from consideration:

$$
\mathrm{Cu}^{2+} \ldots \mathrm{OCH}_{2} \mathrm{CH}_{2} \mathrm{O}^{-} \longrightarrow / / \rightarrow \mathrm{Cu}^{+} \ldots \mathrm{OCH}_{2} \mathrm{CH}_{2} \mathrm{O}
$$

It was possible to assume that reduced forms of oxygen, such as superoxide-anion radical or hydrogen peroxide, are active intermediates in the reaction of EG oxidation. It is well known that superoxide-anion radicals are absolutely unstable in the presence of even traces of water. But, as can be seen from Table 1, introduction of 5 to 10 vol \% water in a solution practically doesn't influence the rate of oxygen consumption.

Influence of $\mathrm{H}_{2} \mathrm{O}_{2}$ additions on oxygen absorption in the reaction of EG oxidation in tert-butyl alcohol mix is presented in Fig.3. One can see that after introductions of $\mathrm{H}_{2} \mathrm{O}_{2}$ in the solution an intensive allocation of oxygen is observed. During 3-5 minutes almost all entered hydrogen peroxide decomposes to oxygen and $\mathrm{H}_{2} \mathrm{O}$. The products of EG oxidation are almost similar to those as in the case without $\mathrm{H}_{2} \mathrm{O}_{2}$ addition.

As it was specified above, numerous reactions of primary and secondary alcohols, glycols, and ketones in the presence of complexes of copper and bases proceed, apparently, via thermodynamic favorable multi electronic mechanism of carrying over electrons from anionic forms of substrates [1-7]. Efficiency of direct interaction of coordinated anions with $\mathrm{O}_{2}$ is in many respects defined by their donor ability. The results of the research of the dependence of EG oxidation rates on solvent nature confirm this. The highest rates of oxidation are observed when the process flows in DMSO or DMF (Table 1), i.e. when the solvents with the highest donating ability of anions are used [11]. When the process flows in water, which has the strongest proton donating ability, an exceptional drop in the reaction rate is observed. 


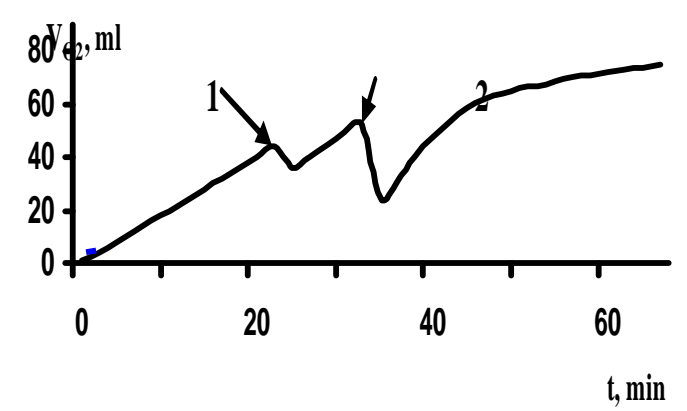

Fig. 3. The curve of oxygen consumption in reaction of EG oxidation ( $20 \mathrm{vol} \%)$ in tert-butyl alcohol. Arrows specify the moment of introduction of $\mathrm{H}_{2} \mathrm{O}_{2} 30 \%$ solution into the reaction mix in the quantity of (mmol): 1.9 (1), 3.8 (2);

$V=25 \mathrm{ml} ;\left[\mathrm{CuCl}_{2} \cdot 2 \mathrm{H}_{2} \mathrm{O}\right]=5 \cdot 10^{-3} \mathrm{M} ;[\mathrm{KOH}]_{0}=0.3 \mathrm{M}$; $T=323 \mathrm{~K} ; P_{O 2}=0.1 \mathrm{MPa}$

High stability of complexes of copper with anionic form of EG to redox transformations in the absence of oxygen and unusually strong dependence of the reaction rate on partial oxygen pressure confirm that direct attack of $\mathrm{O}_{2}$ on a complex of bivalent copper with anionic form of EG is a limiting stage of reaction.

The received kinetic dates of oxidation of EG allow to assume that formation of formic acid results from $\mathrm{O}_{2}$ interaction with chelate complexes $\left\{\mathrm{Cu}^{2+} \ldots \mathrm{A}^{2-}\right\}$ (where $\mathrm{A}^{2-}$ is a dianionic form of EG). Stability of such complexes in alkaline solutions, as it was already marked, is very high. Increase in the concentration of $\mathrm{Cu}^{2+}$ anions leads to increase of concentration of such complexes and linear increase of rate of oxygen consumption and the rate of formic acid formation.

The structure of copper complexes with dianionic form of EG in very strong degree depends on the temperature and nature of solvent used. It is known that stability of chelate complexes of transition metals decreases at temperature rise. Replacement of aprotic solvents by water should also lead to decomposition of copper complexes with EG-dianions, since water is known to be the most powerful hydrolyzing agent.

On the basis of the presented experimental data it is possible to assume that the first stage of the reaction leading to formation of formic acid is the interaction of $\left\{\mathrm{Cu}^{2+} \ldots \mathrm{A}^{2-}\right\}$ complex with $\mathrm{O}_{2}$, where $\mathrm{A}^{2-}$ is a dianionic form of EG. Abnormally strong dependence of the reaction rate on partial pressure of oxygen confirms this supposition. It was noticed that complexes of $\mathrm{Cu}^{2+}$ with anionic form of $\mathrm{EG}$ are very stable in anaerobic conditions (reduction of $\mathrm{Cu}^{2+}$ ions to $\mathrm{Cu}^{+}$does not proceed with measurable rates).

It can be assumed that formic acid is the product of subsequent oxidation of primary product - glycolic acid. However, introduction of glycolic acid in EG solution (in the presence of $5 \cdot 10^{-3} \mathrm{CuCl}_{2} \cdot 2 \mathrm{H}_{2} \mathrm{O}, 0.2 \mathrm{M}$ of glycolic acids and $0.5 \mathrm{M} \mathrm{KOH}$ in tert-butyl alcohol, $323 \mathrm{~K}$ ) does not change the rate of the process and rate of formic acid accumulation. It does not confirm the assumption of participation of glycolic acids as intermediate in $\mathrm{HCOOH}$ formation.

Oxidizing rupture of $\mathrm{C}-\mathrm{C}$ bonds in $\mathrm{EG}$ molecule can lead to methanol or formaldehyde formation, also possible intermediates in formic acid formation. However, methanol even in trace amounts was not detected in the products of EG oxidation.

Earlier it was shown that formaldehyde, which could be formed as intermediate compound, in alkaline environments and in the presence of copper ions is oxidized in high rates but with very low selectivity of formic acid formation [12]. Reaction of EG oxidation to formic acid proceeds, apparently, via the concert mechanism and includes multi-electronic reduction of oxygen without formation of stable intermediates. It is known that such process with participation of $\mathrm{O}_{2}$ as an oxidizer is most favorable from the thermodynamic point of view [13].

The participation of $\mathrm{Cu}^{2+}$ ions in the process of electrons transfer from coordinated anion form of substrate to $\mathrm{O}_{2}$ molecule open the possibility of the reaction proceeding by concert multi-electron mechanism without formation of free radicals. Proceeding of the process by thermodynamically advantageous multielectron mechanism of oxygen reduction allows reaching extremely high rates of oxidation at room temperatures with final products formation selectivity exceeding $90 \%$.

\section{Conclusions}

The experimental data show that by using of oxygen, as the cheapest and non-polluting oxidizer, and simple catalytic system $\left[\mathrm{Cu}^{2+} \ldots\right.$ substrate $\left.\ldots \mathrm{OH}^{\prime}\right]$ it is possible to oxidize with extraordinary rates even such inert in relation to $\mathrm{O}_{2}$ organic compounds as EG. It was shown that by varying conditions of the process it is possible to obtain glycolic or formic acid with high selectivity as a main product. The rates of the processes are near to those of enzymatic reactions in the presence of dioxygenases.

\section{References}

[1] Sakharov A., Mazaletskaya L. and Skibida I.: Kinetika i Kataliz, 2001, 42, 730 .

[2] Skibida I. and Sakharov A.: Ross. Khim. Zh., 1995, 39, 14.

[3] Sakharov A. and Skibida I.: Kinetika i Kataliz, 1988, 29, 118.

[4] Sakharov A., Silakhtaryan N. and Skibida I.: Kinetika i Kataliz, 1996, 37, 393.

[5] Sakharov A. and Skibida I.: Khim. Fizika, 2001, 20, 101.

[6] Skibida I. and Sakharov A.: Catalysis Today, 1996, 27, 187.

[7] Sakharov A. and Skibida I.: Dokl. Phys. Khim., 2000, 372, 785.

[8] Emanuel N., Denisov E. and Maizus Z.: Liquid-Phase Oxidation of Hydrocarbons. Plenum Press, New York 1967.

[9] Habermann N., Jung G., Klaassen M. and Klufers P.: Chem. Ber., 1992, 125, 809.

[10] Demmin T., Swerdloff M. and Rogic M.: J. Amer. Chem. Soc., 1981, 103, 5795. 
[11] Russell G., Bemis A., Geels E. et al.: Adv. Chem. Ser., 1965, $\mathbf{5 1}, 112$.

[12] Skibida I. and Sakharov A.: [in:] Centi G. and Trifiro F. (Eds). New Developments in Selective Oxidation. Elsevier Science Publishers, Amsterdam 1990.

[13] Jones R., Summervile D. and Basolo F.: Chem. Rev., 1975, 79, 139.

\section{КАТАЛІТИЧНЕ ОКИСНЕННЯ ЕТИЛЕНГЛІКОЛЮ КИСНЕМ В ЛУЖНОМУ СЕРЕДОВИЩІ. НОВИЙ ПРИКЛАД ОДНОСТАДІЙНОГО ОКИСНЮ- ВАЛЬНОГО РОЗРИВАННЯ С-С ЗВ'ЯЗКУ}

Анотація. Досліджено реакиію низькотемпературного окиснення етиленгліколю (ЕГ) киснем в присутності солей міді та лугу як у водних, так $і$ безводних розчинах. Знайдено, щчо при низьких температурах (близьких до кімнатної) основним продуктом окиснення ЕГ є мурашина кислота. Підвищення температури від 290-315 K до 350-360 К або проведення реакиії у водному середовищі призводить до різкої зміни напряму перебігу реакиї. ЕГ за таких умов окиснюється 3 переважним утворенням солей гліколевої кислоти. Зміна напряму пов'язана, ймовірно, зі зниженням стабільності хелатних комплексів $\mathrm{Cu}^{2+}$ йонів з діаніонною формою ЕГ. Механізм утворення гліколевої кислоти включає, можливо, стадію двоелектронного відновлення $\mathrm{O}_{2}$ в реакиії кисню з моно аніонною формою ЕГ, координованою на $\mathrm{Cu}^{2+}$ иентрах.

Ключові слова: окиснення, кисень, етиленгліколь, $\mathrm{Cu}^{2+}$ йони, мурашина та гліколева кислота. 